\title{
Intangibles, Global Networks \& Corporate Social Responsibility
}

\author{
Silvio M. Brondoni ${ }^{*}$
}

\begin{abstract}
Network organisations emphasise the importance of corporate and product intangible assets. In global competition, the managerial economics of intangibles imposes new network policies of corporate social responsibility, dominated by global social issues such as economic sustainability, eco-responsibility, worker protection and so on.
\end{abstract}

Keywords: Intangible Assets; Network; Global Competition; Corporate Social Responsibility

\section{Managerial Economics of Intangible Assets}

Globalisation has radically modified the traditional basic principles of industrial output, which are: the static localisation of manufacturing facilities, the presence of workers on the manufacturing site, a massive output of identical goods, stocks of raw and semi-finished materials and finished goods stored close to the manufacturing facilities and consumer markets, and 'long' organisational structures with a rigid, planned and often fragmented division of roles ${ }^{1}$.

In actual fact, on global markets, businesses pursue growth objectives according to logics of 'market-space competition', i.e. with competitive boundaries in which space is not a given, a known, stable element of the decision-making process, but rather a competitive factor, whose profile is established and modified as an effect of the actions/reactions of companies and governments.

On global markets, organisations shift their strategic levers from the qualitativequantitative characteristics of the goods offered to the qualification of the knowledge possessed and managed. Information systems (internal and between companies) thus become a critical factor of corporate development; collaboration between companies is based on specific channels and flows of information; and finally, processes organised sequentially are transformed into relationships formed within 'project-oriented networks' that go all the way to the virtual enterprise ${ }^{2}$.

\footnotetext{
*Full Professor of Management, University of Milan-Bicocca (silvio.brondoni@ unimib.it)
} 
As markets globalise, numerous barriers collapse, intangible features supplant tangible elements, time becomes a crucial function of competition, mobility (of people, goods, knowledge and ideas) emerges as a vital condition of an organisation's very existence and new systems of relationships take hold in the context of global managerial economics.

Corporate policies based on an 'enlarged' competitive space (market-space management) postulate the end of the direct and proximity control limits that imply the 'physicality' of activities, in favour of companies characterised by the predominance of intangible assets, competitive adaptability and managerial flexibility.

Flexible forms of organisation presuppose corporate structures in which the crucial importance of intangible assets is expressed by the space of relationships, action/reaction times and relationships of competition and collaboration.

Where space is concerned, we should point out first of all that corporate processes (research and development, production, sales, etc.) are not necessarily located with a stable hierarchy in a given place. For example, manufacturing processes are usually spread over different sites and companies and do not gravitate around the parent company, because the information flows that generate production make it possible to physically relocate output (at least in part) anywhere in the world, directly from individual units and without constraints of time.

Where time is concerned, 'market-space management' influences the timing efficiency of corporate processes; networks with different structures and locations replace 'stably' located facilities and processes with a sequential matrix, with the result that time compresses the moments of inertia and exploits the manufacturing requirements of the operating units that make up the network.

And finally, in terms of the functions performed, 'market-space management' tends to propose a fundamental change in relations and collaboration with customers, partners and co-makers, exceeding the typical limits of 'interface physicality' to establish closer, more selective interaction between inter-companies teams without proximity constraints.

Today, on global markets, companies tend to establish a complex vital system, oriented to competition, with a managerial horizon that dominates the traditional dimensions of space and time (i.e. referred to a limited environment, which makes it possible to measure the performance and competitive position of an elementary company-asset-market combination at a given time).

'Market-space competition' conditions outline sophisticated competition boundaries with an international matrix, in which space and time combine to create and alter the 'relevant competitive context', which also makes it difficult to evaluate possible market domination using the usual performance and position indicators. It is therefore difficult to limit the competition space generated by market-space management behaviour to sectors of activity, and it is more correctly ascribable to the management of corporate and product intangible assets, which temporarily help to classify the competitive profile of specific companies.

The managerial economics of intangible assets acquires specific importance in global over-supplied markets (i.e. where output exceeds the absorption capacity of demand and increasingly sophisticated products are rendered rapidly obsolete by easy imitation and the increasing non-loyalty of demand). On open markets, in fact, 
over-supply becomes a structural development factor of companies, which plan the gradual over-abundance of goods (which can be manufactured at ever-lower costs due to continuous technological developments) in competitive terms. On these open and fiercely competitive markets, the economics of intangible assets emphasises the role of the large multi-market and multi-business corporation, while it helps to stabilise the competitive structures of global markets, enhancing the central importance of competitive alliances while it reduces the significance of the sector of activity as the context where competition is played out ${ }^{3}$.

\section{Global Markets, Managerial Economics and Product Intangibles}

On global markets, an organisation's strategic lever focuses on the degree of qualification of the knowledge owned and managed.

In particular, a global company's success is conditioned by its ability to manage the system of product intangible assets (product design, brand, pre/after-sales services) and corporate intangible assets (corporate culture, corporate identity and information system) from a competitive or market-driven point of view ${ }^{4}$.

\subsection{Product Design}

Corporate imitation and innovation processes have come to represent a primary condition to stand up to global competition on the markets, which takes the shape of identifying the supply chain with 'new' characteristics to propose to customers that change in time and space.

$\square$ Fiat Automobiles is preparing to launch the Fiat Mio in Brazil, an innovative, ultra-compact high-tech zero emissions concept car. It is 2.5 metres long, 1.56 metres wide, and 1.53 metres high, with futuristic lines and a cabin that seats two, making it the answer to the Smart. The Fiat Mio is the fruit of research undertaken with potential customers and with the 'www.fiatmio.cc' web community, which draws together 14,000 people in 140 countries (2010, August).

The design of products with 'new' tangible and intangible components is closely linked to market studies and research carried out to identify particular consumer needs ${ }^{5}$.

Product design therefore uses technical specifications to define the measurements and functions that qualify a product or service, in order to identify and organise the distinctive specifications of the supply chain, and to develop goods and services based on analysis of the needs of demand (customer satisfaction).

On global markets, where competition is intense, customer satisfaction is a necessary condition (in other words a requirement that all competitors must comply with) but one that is nonetheless not sufficient to overcome competitors. Achieving a differential advantage in terms of product design therefore means designing a product based on the best interpretation of specific distinctive characteristics, and to this end, information must be collected about competitors (in terms of 
competitive intensity, marketing capability, strengths and weaknesses), to understand their targets and to predict their future actions, even monitoring the threat of new competitors and any replacement products, i.e. products that meet specific consumer needs in a different way or at a lower cost. A competitive market survey thus entails collecting, managing and processing reliable data about competitors in real time, classified by time, geography and profitability.

\subsection{Product Brand Equity}

From a managerial point of view, the brand sums up the awareness and image that a company is able to establish with its target public, and may be defined as 'a specific relationship established with a given market for the success of a given product $^{\prime 6}$. This specific relationship is expressed above all by functional and symbolic values that demand attributes to a specific product through the brand.

Defining the brand as the relationship between a company's products and demand leads us to consider the brand itself as a result: a brand sums up the knowledge (i.e. the awareness and image) of a given product in demand, but also a specific product's ability to relate to a givern need on the part of the buyer ${ }^{7}$.

The increased complexity of the value in use of goods and services that is evident in advanced societies, and the purchasing behaviour of global demand, oblige companies to pay greater attention to corporate activities designed to establish specific market relations, where the brand represents an intangible asset for the company and, as such, it can be an integral part of corporate equity.

With reference to the brand as an intangible asset, brand equity defines the state, at a given time, of the specific relationship a given product establishes with a particular market. Brand equity is therefore the functional value of the brand, and a projection, at a given date, of knowledge of the brand (i.e. its awareness and image) that has been established with the target demand. Brand equity is a complex intangible asset because it is the result of numerous determinants and for the company it represents a potential source of value.

The phenomenon of the brand as the competitive equity of the large business has become particularly evident in recent years. In global markets, 'brand equity' becomes a fundamental intangible asset, which large companies sustain with integrated communications policies, paying attention to goals of performance and corporate responsibility.

On global markets, where competitive dynamics are becoming increasingly fierce and companies' strategic management models are based increasingly on the time factor, a significant brand equity reveals the existence of a positive differential in relation to competitive products, which is therefore able - at least temporarily - to guarantee a certain stability to a company's products: "under the protective shield of the brand, products are renewed in a context of credibility, legitimacy and affectivity, thus reducing the risk and uncertainty that weigh on corporate activities" $"$. 


\subsection{Pre-Sales Services and After-Sales Services}

Pre-sales services are designed and delivered by manufacturers and/or financial companies (subsidiaries or associates of the producers) directly to end buyers or to sales intermediaries (retailers, wholesalers, prescriptors).

In global markets, pre-sale services break down into two main types: on one hand, the services planned by product marketing and put in place to motivate primarily on a rational basis - the decision to purchase a particular product; and on the other hand, the services designed to create specific advantages in transaction costs and therefore destined to generate particular choice motivations, that are exclusively economic and financial. The first type of pre-sales services tends to target purchasing motivation and to endorse corporate investment in brand policy and after-sales services. This type also includes pre-sale product consulting services, which may be offered to consumers through personal contacts, or provided online to the trade and to potential customers. Primarily financial services, on the other hand, see logistics and reverse logistics (pre-sale contracts to dispose of exhausted products, such as televisions, refrigerators, etc.) as typical examples of pre-sales services that address sales intermediaries, while pre-sale activities that address end buyers underline the growing importance of consumer credit. The latter is provided by specialist structures, although these are often extraneous to product policies, and exerts a strong 'flattening action' of the product's distinctive characteristics, weakening the branding value and competitive relevance of after-sales services (which are subordinate to elementary factors of product sales bargaining).

In global markets, after-sales services (servicing, product up/down-grading, maintenance, repairs, spare parts, learning and training, trade merchandising) guarantee the full, functional use of products and services after the purchase. Aftersales services (which are delivered personally and create information flows from the clientele to the company) generate huge costs, above all in the presence of high customer satisfaction targets and close checks on the intervention times and methods of the dedicated structures. On global markets, after-sales costs (often sustained before the sale) and the advantages of customisation (in the medium/long-term) conflict with profitability targets, with the result that key services are contracted out and different after-sales outsourcing policies are developed, defined as:

- 'outsourcing for value', which contracts out after-sales services to maximise the profitability of the branding policy and pre-sales services (particularly logistics for trade and consumer credit for customers), to which the repurchase and fidelity of after-sales services are subordinated (therefore from the point of view of business value first of all). This occurs in companies that operate in over-supplied economies, with a competitive trade sector and generally not-loyal consumers;

- 'outsourcing for branding', which, having contracted after-sales out, aims to highlight the brand and repurchasing loyalty (satisfaction first of all), as we see in big companies and more generally in global economies where competition is controlled, with active final demand and trade; 
- 'outsourcing for cost', designed to minimise the costs of the services delivered (profit first of all), structuring the operating centres with 'cascade contracts' and moving virtual centres - like call centres - to countries with low manpower costs or strong incentives on localisation. Typical examples of this are the corporations that are able to govern global scarcity economies (like fuel, mobile telephones, etc.), with entirely passive trade and consumers. This context also covers 'local monopolies', where after-sales basically 'keep the clientele away'.

\section{Global Markets, Networks and Corporate Intangible Assets}

In recent decades, numerous large corporations have been induced to develop plans to extend their activities, according to a global corporate vision, combining their distinctive competitive skills and the development of vaster boundaries of economies of scale (market-space competition) (Raiport and Sviokla 1994, 145). With globalisation, the company abandons the static, limited conception of competition space and attributes the development of particular partial competitive advantages to specific geographical contexts, where they will be coordinated in a more complex system of corporate operations and profitability (market-space management $)^{9}$.

The deep and sudden financial crisis that has overwhelmed the world economy marks the start of the second stage of globalisation, and numerous economic paradigms, the competitive scenarios and the balance of power between large corporations are changing.

Market-space competition demands managerial capabilities that can govern ramified, disseminated and interconnected organisations (networks). Network relations are managed in such a way as to permit control of alliances, equity (international joint ventures, equity investments) or non-equity (shared manufacturing/co-makership, R\&D partnerships, outsourcing, supply-chain partnerships, cooperative marketing, licensing, franchising, etc.).

The evolution of corporate management from a situation of uniformity and rigidity to contexts dominated by flexibility and variety (which exploit synergies and network relations) makes it necessary to consider network performance metrics, i.e. performance indicators that can incorporate local results and global performance. The latter must be expressed as the sum of results emerging from actions and relations activated in specific competitive market-spaces and must clarify the time and value of intangibles in partial and overall corporate evaluations.

In global markets, organisations emphasise 'knowledge management'; collaboration between companies is achieved by the creation of specific information channels and flows; and finally, company processes are developed inside networks, which postulate the optimisation of performances by dividing operating structures on the basis of space, time and the function performed. In other words, by imposing corporate behaviour focused on competition (market-driven management).

The pooling of intangible resources pursued by global networks that operate in 'extended' competition spaces focuses business economics on non-elementary key 
factors (technology, communication, product intangible assets), whose value is determined not on the basis of the degree of exploitation, but of the intensity with which a specific key factor is shared with structures outside the organisation, specifically by raising the value of the corporate intangible assets ${ }^{10}$.

Corporate intangible assets that can be governed by the company, and allow complex corporate structures (networks) to be managed without any geographical constraint on their operations, relate to: the success and consolidation of a specific culture of the organisation, the design and management of the corporate information system, and finally, the creation and enhancement of a specific corporate identity.

\subsection{Corporate Culture}

The crucial importance of a corporate culture is particularly evident today in large corporations. In fact, larger companies tackle globalisation according to a concept of competition space that exceeds the confines of physicality and is extended by the exploitation of intangible products (market-space competition) ${ }^{11}$.

In complex organisations oriented to passing the physical boundaries of competition (market-space management), the central importance of the corporate culture in the management of internal, external and co-makership relations appears evident, because these relations are based on close and far-flung interactivity, which can be achieved in real time without the conditioning of physical space ${ }^{12}$.

The corporate culture expresses a company's personality, permeating every manifestation of corporate life, in its relations with the outside world (customers, intermediaries, competitors) and above all inside the organisation, in relation to numerous operating units. They are organised by type of relationship (employees, co-makers, partners) and disseminated in space, but nonetheless oriented to homogeneous (overcoming the specificity of local conduct) and synchronous behaviour at an international level (i.e. with action/reaction times that are independent of geographical location).

In external relations, in particular, a company's personality conditions its image, i.e. the differential competitive characteristics. On the basis of the relationships established, customers, shareholders, financiers, suppliers, public authorities, distributors, competitors, etc., together determine the image profile, which they value continually in relation to their own perceptive and cognitive schemes.

Inside the organisation, the corporate personality strives to establish a high level of identification, to achieve a strong alignment of its goals, interests and behaviour (Salvioni, 1997). A similar alignment clarifies the company's guiding values and rules of conduct, laying the foundations to act together to reach common goals.

\subsection{Corporate Information System}

In companies that consider the operating space as a competitive factor (marketspace competition) (Garbelli 2004), the information system is a crucial intangible asset. Its connotations derive from the dominant culture in the organisation and configure the integration and adaptation strategies which, over and above geographical and administrative boundaries, enable an organisation to operate in 
harmony with the many environments in which it works, thanks to a specific corporate identity that is unique and cannot be replicated.

A vast, mutating operating space presupposes the development of continuous propositive relations and to this end the information system is the necessary vehicle for the critical evaluation of the potential and limits that are expressed inside and outside an organisation. The process that manages communication flows on the basis of evolved information systems therefore makes it possible to constantly acquire and spread information and knowledge that interact with the sum of existing knowledge, within complex corporate structures.

In terms of the competitive management of space (market-space management), the corporate culture plays a central role in configuring the information system as a tool to govern internal and external communication flows. It therefore establishes the integration and adaptation strategies which, over and above geographical and administrative boundaries, enable an organisation to operate in harmony with the many environments in which it works, thanks to a specific corporate identity that is unique and cannot be replicated. In this context, in particular, the information system acquires particular significance in the management of so-called 'demand bubble' and in establishing prices oriented to competition (competitive pricing).

Overcoming the physical boundaries of competition and the competitive condition of continuous innovation, it squeezes a company between the contrasting forces of 'customer satisfaction' (oriented to increasing the value of goods at decreasing costs) and competition on a vast scale, with the result that the increase in a company's size becomes a sort of precondition for it to continue to compete ${ }^{13}$.

The performance of global companies is therefore founded on the piloted fragmentation of demand and the capacity for innovation guided by 'customer satisfaction', managing the expectations of potential customers over and above the traditional logic of segmented demand.

Market globalisation and the increased volatility of choice preferences radically change the competitive goalposts: supplies with a high degree of marketing differentiation are very profitable only for organisations that can draw on market knowledge and management capability to intercept demand variability and therefore to create continuous consumption niches (bubbles), being the first to meet them (time-to-market) and achieving a consistent income by swiftly abandoning the demand bubble (time-based competition), at the arrival of competitors-imitators.

\subsection{Corporate Identity}

And finally, global managerial economics that is strongly competition-oriented (market-driven management) recognises that a corporate identity is a fundamental factor of development.

On global markets, an organisation tends to pursue control of global competition space as a whole, independent of specific products but related to a brand equity referred to a 'corporate brand', which is increasingly identified with a 'network corporate brand'.

$\square$ Procter \& Gamble sold its pharmaceutical products division to the U.S. company Warner Chilcott (2009, August). 
Unilever recently left the frozen food market and is now leaving both the olive oil and the jam markets. On the other hand, the multinational's decisions are piloted by the need to ensure a dividend to its shareholders and therefore, like other multinationals in the food sector, it is abandoning products with a low added value (2008, August).

Nestle has left the cheese market (selling the Locatelli brand), the cured meat market (selling several brands, including the historical Vismara brand), and the olive oil and fats market (Sasso and Berni, among other brands). More recently, it has also left the pasta and bread substitute market (selling the Buitoni and Pezzullo brands) (2009, February).

The Barilla Group has sold the chain of German bakery chain Kamps $(900$ bakeries, five plants, one thousand employees, sales of approximately $€ 200$ million, the leading German chain, acquired by Barilla in 2002). It was sold to the German Equity Partners III fund and was part of Barilla's programme to rationalise non-strategic assets, like the sale of the Gran Milano (panettone) and Quality Bakers Nederland (pastries) brands (2010, August).

$\square$ Volvo has been sold to Geely of China. The U.S. car-maker Ford has concluded the sale of its Swedish division to the Chinese company Geely Holding Zheijang, for a total of \$1.8 billion (2010, August).

In a network logic, companies are exploit licensing, i.e. managing the rights to use a trademark, in order to grow in size, surpassing the physical boundaries of competition.

In the past, licensing was limited to the commercial exploitation of trademarks with vast recognition. In fact, more appropriately, on global markets licensing can be considered as a way of exploiting a network's brand equity, and therefore as a company policy designed to extend the brand's competitive values of recognition and image in sectors outside the company's core business. As a result, in very competitive contexts, the possibility of earning royalties by exploiting a wellknown trademark is absolutely subordinate and accessory to the opportunity to develop the brand equity ${ }^{14}$.

The development of the corporate identity may also be pursued through franchising. Franchising systems are based on networks of companies with a central structure (the franchisor) linked by economic-contract relations of comakership to satellite organisations (franchisees), which are given managerial autonomy within a specific group entrepreneurial project.

Affiliation through franchising allows a company to be part of a manufacturing and distribution formula (usually with an exclusive for a specific product) that for its very nature already surpasses the traditional physical constraints of competition. 
On global markets in particular, the spatial flexibility typical of franchising is specifically corroborated for development. In fact, peculiar intangible factors of competition become crucial, such as: the ramification and diversification of the affiliates; the consistency between the brand and the integrated communication policy of affiliates; the sophistication of the information tools; and finally the system of organisational coordination tools.

\section{Global Markets, Networks and the System of Intangible Assets}

In global markets, the success of network companies is conditioned by their capacity to manage intangible assets from a compretitive point of view. What is more, in global markets, networks operate in different geographical areas with very different 'product portfolios' and can therefore make up supplies with dissimilar relations of intangibility/tangibility ${ }^{15}$.

In a network, the intangible assets governable by the company constitute a closely integrated 'system', where each intangible component takes value from the others and is connected to them in various ways. Moreover, the evaluation of the corporate intangible assets as a system implies that the whole identified is not just the simple sum of the elements that make it up, but also includes the interaction that develops between them. In this way, the 'intangible assets' that are considered the elements that make up a system, attribute value to the company they belong to, not only autonomously, but above all because they are related with each other and with the so-called system of corporate intangible assets ${ }^{16}$.

Product and corporate intangible assets have different use hierarchies that reflect the competitive intensity that has developed on the markets, and these hierarchies (corporate-product or product-corporate) constitute a key factor of competitiveness on global markets. In fact, in relation to the competitive system that it has to address with its products, global corporate management may put the system of corporate and product components together differently, proposing differentiated products to specific markets in response to demand segmentation, or to temporary groupings of inhomogeneous buyers linked by an interest in a supply chain profile (demand bubbles) ${ }^{17}$.

The way they combine intangible assets therefore allows companies to develop complex models of competitive action and reaction on the market, which helps them to control demand.

In fact, in situations of particularly intense competition, in the hierarchy of intangible assets corporate intangible assets tend to prevail over product intangible assets; on the contrary, when competition is not intense (i.e. when relations between competitive networks are limited) product intangible assets take on a priority role with respect to corporate intangible assets.

The capacity to effectively manipulate product and corporate intangible assets in relation to the competitive system of each business therefore reveals a structural relationship between intangible assets at a corporate level (corporate culture, information system and corporate identity) and at a product level (brand, pre/aftersales services, product design) related to which competitive intensity (i.e. the degree of intensity, direction and duration of relations between competitors on open 
markets). The corporate and product intangible assets may therefore be described as a system when it underlines the importance of the link between the elements that make it up, with strategic and operational consequences for global corporate management.

\section{Intangible Assets \& Network Social Responsibility}

Because of their ever-larger size on one hand and their market power on the other, which can take stronger networks to positions of global oligarchy, as in the case of energy companies, global network organisations reveal crucial factors of development in the pursuit of stable local supremacy, due to the diffidence and critical sensitivity of opinion makers (consumers, shareholders, employees, suppliers, media, etc.), who are increasingly interconnected, informed and delocalised with respect to the production and consumption of the goods ${ }^{18}$.

Corporate globalisation policies provoke widespread criticism (economic growth concentrated in countries with high R\&D intensity, 'targeted' scientific research, limited attention to genetic transparency, to the environment, to food safety and to conditions of social exclusion, free growth, without global standards or controls on waste, refuse and rubbish), which is widely echoed because mass communication in the $21^{\text {st }}$ century is also globalised (and above all is no longer one-way and linear, from the issuer to the receiver).

\subsection{Fidelity and Non-Fidelity, Corporate Identity and Network Responsibility}

On open global markets, a structural manufacturing overcapacity generates volumes of goods that far exceed the capacity of demand to absorb them. However, the qualitative dimension of over-supply is even more dramatic for companies, because demand - now accustomed to having a wide range of alternatives expects the variety of supply to expand constantly.

What is more, end buyers not do appear at all disoriented by this accelerated innovation on the part of manufacturers (who compete with increasingly sophisticated goods at ever-lower prices), on the contrary they intervene themselves to change purchasing processes, making informed, opportunistic choices in terms of spending times and methods.

In other words, new purchasing behaviour, in which the end buyer is in a 'circular relationship' with the trade and with manufacturers, that adopts purchasing models based on non-loyal behaviour, which joins the familiar loyalty mechanisms.

In fact, non-loyalty is expressed by a critical evaluation of the value of specific goods (and therefore, first and foremost, of the brand's promise and credibility): the decision to purchase may therefore change radically in time and/or in space - or be slow to manifest itself, postponing the purchase - because it tends to optimise changing information about the differentiation value of the asset (brand benefit).

Non-loyalty questions the inertia mechanisms typical of loyalty and induces manufacturers and the trade to activate fidelity programmes, which target non-loyal demand with enticing proposals, to establish a dynamic purchasing relationship ('stop \& go') to be channelled into a 'market-space competition' logic. 
Fidelity therefore exploits the profitable but volatile advantages that are typical of non-loyal relationships, and for this purpose it absorbs massive investment, which brands must target at the information system and the development of intangible product factors (brand responsibility, product design, cost-driven production).

Brand equity sums up the effects of a company's communication undertaken to develop the relations of brand with the market, and as a result it also defines the state of the company's competitive advantage in relation to specific markets for specific products.

From a 'market-space competition' point of view, brand equity may be exploited to overcome the physical context of competitiveness from different angles, which in some cases give priority to the potential value of specific brands (for example, with 'brand extension' and 'brand portfolio' policies), while in other contexts they focus on the power of the brand for the development of the company as a whole (corporate identity).

The brand extension policy represents a 'natural' strategy to expand their competition space for companies that pursue corporate development by exploiting specific corporate intangible assets, destined to penetrate new areas of activity (product categories).

A more sophisticated and expensive form of expansion of competitive boundaries (market-space competition), still based on the brand equity of specific products, could be developed by recourse to the 'brand portfolio'. In different cases, the 'brand portfolio' may help to expand the competition space. First of all, a wide range of brands may be necessary to 'create a market'. A single product is generally never in a position to satisfy evolved demand of vast proportions. What is more, a multi-brand portfolio policy that competes with several brands on a single market, makes it possible to market the brands with the lowest profile for tactical purposes (for example, to limit the possibilities for 'brand extension' by the competition), or to defend the main brand against price cutting policies, which could jeopardise the image of the leading brand. And finally, a 'multi-brand portfolio' policy may be necessary to meet specific regional market requirements, or spatially defined geographical-administrative contexts (as in the case of large international beer producers).

\subsection{Cost-Driven Production and Network Corporate Responsibility}

From the point of view of manufacturing processes, the highly intense competition that corporate networks have to address on today's markets derives from the complex interaction of numerous factors: the over-supply of numerous products, well above the capacity of demand to absorb it, the central importance of the time factor in manufacturing processes and demand satisfaction, and environmental instability.

A company that addresses this complexity tackles the manufacturing issue, and therefore its own relation with time and with space (manufacturing localisation) from a new angle. Markets dominated by over-supply stimulate companies to search for solutions that can satisfy the timing (reduction of action-reaction times) and spatial demands of manufacturing (control of strategic areas with neighbouring manufacturing units). Companies seem to respond to these needs with complex 
mechanisms designed to develop competitive relations 'individually' or in association with other companies, whether suppliers, distributors or even competitors.

\begin{abstract}
Important alliance between Nokia (mobile telephones) and Microsoft (software). Very soon Windows Phone software from Microsoft will be inserted in the Smartphones from the Finnish company Nokia. The new alliance was accompanied by the announcement of substantial future job cuts at Nokia, in many parts of the world, including Finland. Microsoft is counting on the alliance with Nokia to impose the Bing research engine and its mobile telephone platform on the market. For Nokia, on the other hand, it is an opportunity to launch a new management team and an organisational structure 'with a precise focus on speed, results and accountability' (2010, December).
\end{abstract}

Manufacturing localisation is therefore becoming a particularly complex problem and the criteria usually adopted in the choice of a location (proximity to supply markets, country incentives, etc.) must be supplemented with a range of additional considerations. As a result, the choice of manufacturing localisation abandons the sphere of static, long-term evaluation, typical of proximity relations between the manufacturing and consumption of a product. At the same time it is not conditioned in the long term by public measures to encourage settlement, giving priority to the critical nature of certain competition costs (R\&D, local antitrust mechanisms, marketing, etc.), which are very sensitive for a company's management and development. As a result, manufacturing localisation takes on specific connotations of dynamism in time and in space.

With globalisation, therefore, the decision to localise production brings out the most competitive corporate strategies, which focus specifically on:

- 'upsizing' policies (implemented with acquisitions, mergers, joint ventures and alliances), designed to control the manufacturing agreements with certain suppliers (co-makers) and above all with the competitor system. The success of increasingly complex products and services (and related added value processes) shifts competition to a chain of added value and the network of competitors, since the competitive advantages derive from the integration of management functions that go beyond the corporate boundaries of client, manufacturer and supplier;

- policies to develop the company's 'corporate profile', which is considered a competitive factor. The policy to state a corporate personality, which is valued inside and outside the organisation, aims to establish a specific 'invisible asset'. The corporate culture thus constitutes a determinant that is intended to extend the competitive space, making it possible to shift the physical boundaries of manufacturing outside the company (for example, by backing up traditional manufacturing processes with outsourcing or networking policies), while maintaining close control over the identifying characteristics of brand equity. 
In companies that focus on 'market-space management', decentralising manufacturing therefore presupposes raising the profile of the 'corporate identity'. In company networks set up to compete on open markets (market space management), the attraction of the 'network identity' thus prevails over the local opportunities of the 'development paths'. At the same time, the planned and encouraged rotation of personnel (by entrance/exit times and conditions) is replacing traditional continuous training programmes (linked to the static nature of the manufacturing plants). And finally, salary developments (once based on seniority) have been replaced by incentive plans on entry and by selective development plans, which tie salaries to achievement of economic and metaeconomic 'tasks' (network corporate responsibility) ${ }^{19}$.

\subsection{Global Markets and Network Social Responsibility}

Because of the logic of continuous growth typical of 'market-space competition', corporate development based on an 'enlarged' competition space (market-space management) tends to generate mega-organisations, with supranational 'top management power' that can occasionally create international ethical problems in relations with Nation-States. The global networks that operate in 'enlarged' competition spaces (enhancing and exploiting the intangible assets of brand equity, the information system and the corporate culture) have access to market information and socio-economic forecasts that are very detailed, up-to-date and timely, and above all more extensive and sophisticated than the knowledge that governments can access for local development.

For some time, large corporates have operated in network structures to achieve vital economies (procurement, manufacturing, distribution, communication, marketing), targeting the enormous economic-financial advantages achievable by growing economies (supply-driven management) on corporate policies to satisfy demand that focus as a priority on competitive confrontation (market-driven management) ${ }^{20}$.

In today's scenario of global 'hypercompetition', organisations shape supply innovation and create 'local' consumption 'bubbles'.

'Hypercompetition' strategies break the static, monolithic rules of the company that plans, produces and sells by the rules of absolute proximity (local market) or relative proximity (international market), asserting more complex and articulated global structures that disregard traditional rules of corporate responsibility (for example, in terms of quotas of national workers to hire) and 'local' conduct based on social responsibility. Instead they refer to often impalpable standards of 'network social responsibility' (which envisages the fragmentation of corporate responsibility centres and various hierarchical levels of social responsibility, dispersed in space and changing in time, and often not easy to identify).

Globalisation also imposes a model of systemic competition on the networks, to be developed according to a logic of 'market-driven management'; in other words, a 'philosophy of management oriented to the market', in which 'customer value management', or sales to 'demand bubbles' (instable aggregates of customers that replace demand segments) prevail, in direct and continuous confrontation with the competition. 
A competitive approach to the market is therefore manifested from the bottom up, to 'force' the intersection of supply and demand, developing exchange and communication flows (push/pull communication) $)^{21}$. On global markets, marketdriven management introduces a sophisticated market strategy, implemented by large corporations, which is first and foremost designed to overcome local protectionist measure (ceilings on imports, mutual access to markets, promotion of national products; sanctions against brand forgeries) put in place in nation-states that still operate with obsolete corporate responsibility and corporate social responsibility logics 22 .

In fact, for over twenty years, global markets have imposed a market-driven management strategy on companies. This demands a network culture and local organisations motivated by results, market policies that monitor the instability of the competition and the variability of demand; the reorganisation of the company to 'global business' rather than to markets and products, and the preparation of new metrics to evaluate intangible and tangible factors and to stimulate corporate performance. In other words, global managerial economics based on new paradigms of corporate accountability, that supports the 'corporate social responsibility' of the network. On one hand, the priority 'social global dimensions' (for example, economic sustainability ${ }^{23}$, eco-responsibility, equal status for workers, etc.) demand the strengthening of the worldwide organisms responsible for monitoring companies, and the formulation of new rules and standards that are in tune with the global contexts of network competition on the other.

\section{Bibliography}

Albanese Fabio, Merchandising and Licensing to Improve Brand Equity. The Coca-Cola Case, Symphonya.Emerging Issues in Management (symphonya.unimib.it), n. 1, 2000-2001. http://dx.doi.org/10.4468/2001.1.06albanese

Annan Kofi, The Gobal Compact. Corporate Leadership in the World Economy, Symphonya. Emerging Issues in Management (symphonya.unimib.it), n. 2, 2002.

http://dx.doi.org/10.4468/2002.2.02annan

Best Roger J., Market-Based Management, Prentice Hall, Upper Sadle River, 2004.

Bleeke Joel, Ernst David, Collaborating to Compete: Using Strategic Alliances and Acquisitions in the Global Marketplace, John Wiley, New York, 1993.

Borgonovi Elio, Sustainable Economic Growth in the Global Society, Symphonya. Emerging Issues in Management (symphonya.unimib.it), n. 2, 2007.

http://dx.doi.org/10.4468/2007.2.06borgonovi

Brondoni Silvio M., Market-Driven Management, Competitive Customer Value and Global Network, Symphonya. Emerging Issues in Management (symphonya.unimib.it), n. 1, 2009. http://dx.doi.org/10.4468/2009.1.02brondoni

Brondoni Silvio M., Market-Driven Management, Competitive Space and Global Network, Symphonya. Emerging Issues in Management (symphonya.unimib.it), n. 1, 2008.

http://dx.doi.org/10.4468/2008.1.02brondoni

Brondoni Silvio M., Managerial Economics and Global Competition, Symphonya. Emerging Issues in Management (symphonya.unimib.it), n. 1, 2005.

http://dx.doi.org/10.4468/2005.1.02brondoni 
Brondoni Silvio M., Ouverture de 'Marketing Research \& Global Markets', Symphonya. Emerging Issues in Management (symphonya.unimib.it), n. 2, 2003.

http://dx.doi.org/10.4468/2003.2.01ouverture

Brondoni Silvio M., Network Culture, Performance and Corporate Responsibility, Symphonya. Emerging Issues in Management (symphonya.unimib.it), n. 1, 2003. http://dx.doi.org/10.4468/2003.1.02brondoni

Brondoni Silvio M., Global Markets and Market-Space Competition, Symphonya. Emerging Issues in Management (symphonya.unimib.it), n. 1, 2002. http://dx.doi.org/10.4468/2002.1.03brodoni

Brondoni Silvio M., Brand Equity and Brand Policy, Symphonya. Emerging Issues in Management (symphonya.unimib.it), n. 1, 2000-2001. http://dx.doi.org/10.4468/2001.1.02brondoni

Brondoni Silvio M., Jean-Jacques Lambin, Ouverture de 'Brand Equity', Symphonya. Emerging Issues in Management (symphonya.unimib.it), n. 1, 2000-2001. http://dx.doi.org/10.4468/2001.1.01ouverture

Castells Manuel, Informationalism, Network, and the Network Society: A Theoretical Blueprint, Castells Manuel (ed.), The Network Society. A Cross-Cultural Perspective, Edward Elgar, Northampton, 2004.

Corniani Margherita, Push and Pull Policy in Market-Driven Management, Symphonya. Emerging Issues in Management (symphonya.unimib.it), n. 1, 2008.

http://dx.doi.org/10.4468/2008.1.05corniani

Corniani Margherita, Digital Marketing Communication, Symphonya. Emerging Issues in Management (symphonya.unimib.it), n. 2, 2006.

http://dx.doi.org/10.4468/2006.2.04corniani

Corniani Margherita, Demand Bubble Management, Symphonya. Emerging Issues in Management (symphonya.unimib.it), n. 1, 2002. http://dx.doi.org/10.4468/2002.1.08corniani

Day George S., Market- Driven Winners, Symphonya. Emerging Issues in Management (symphonya.unimib.it), n. 2, 2000-2001. http://dx.doi.org/10.4468/2001.2.02day

Day George S., The Market-Driven Organization, The Free Press, New York, 1999.

Day George S., The Market-Driven Strategy, The Free Press, New York, 1990.

Day George S., Reibstein David J., Managing Brands in Global Markets, Gatignon H.,. Kimberly J.R, Gunther R.E. (eds.), Alliances on Globalizing, University Press, Cambridge, 2004. http://dx.doi.org/10.1017/CBO9780511522093.009

de Leersnyder Jean-Marc, Corporate Culture and Geopolitics, Symphonya. Emerging Issues in Management (symphonya.unimib.it), n. 2, 2002. http://dx.doi.org/10.4468/2002.2.06deleersnyder

Dolan Robert J., Simon Herman, Power Pricing, Free Press, New York, 1996.

Doyle Peter, Value-Based Marketing, John Wiley, Chichester, 2000. http://dx.doi.org/10.1080/096525400446203

Gnecchi Flavio, Market-Driven Management, Market Space and Value Proposition, Symphonya. Emerging Issues in Management (symphonya.unimib.it), n. 2, 2009. http://dx.doi.org/10.4468/2009.2.04gnecchi

Hagel III John, Armstrong Arthur, Net Gain: Expanding Markets Through Virtual Communities, Harvard Business School Press, Boston, 1997. 
Hamel Gary, Prahalad C.K., Competing for the Future, Harvard Business School Press, Boston, 1994.

Hitt Michael A., Ireland R. Duane, Hoskisson Robert E., Strategic Management. Competitiveness and Globalization, 4th ed., Thompson Learning, Cincinnati, 2001.

Keegan Warren J., Green Mark C., Global Marketing, $5^{\text {th }}$ ed. Pearson, Upper Saddle River, 2008.

Kotler Philip, Pfoertsch W., Business-to-Business Brand Management, Springer, Berlin, 2006.

Kotler Philip, Hoon Ang Swee, Meng Leong Siew Tiong Tan Chin, Marketing Management. An Asian Perspective, Pearson, Singapore, 2003.

Lambin Jean-Jacques, Changing Market Relationships in the Internet Age, UCL, Louvain, 2008.

Lambin Jean-Jacques, Brondoni Silvio M., Ouverture de 'Market-Driven Management', Symphonya. Emerging Issues in Management (symphonya.unimib.it), n. 2, 2000-2001.

http://dx.doi.org/10.4468/2001.2.01ouverture

Lambin Jean-Jacques, Market-Driven Management, McGraw-Hill, London, 2000.

Ohmae Kenichi, Globalization, Regions and the New Economy, UCLA, Center for Globalization and Policy Research, Working Paper n.1, January 2001.

Ohno Taiichi, Toyota seisan höshiki, Diamond Ed., Tokyo, 1978 ( $1^{\text {st }}$ eng. tranl.: Ohno Taiichi, Toyota Production System: Beyond Large-Scale Production, Productivity Press Inc., New York, 1988).

Porter Michael E., Competitive Advantage: Creating and Sustaining Superior Performance, Simon \& Schuster, New York, 1985.

Rayport Jeffrey F., Sviokla John J., Managing in the Marketspace, Harvard Business Review, vol 72, n. 6, 1994, pp. 141-150.

Salvioni Daniela M., Market-Driven Management and Corporate Governance, Symphonya. Emerging Issues in Management, (symphonya.unimib.it), n. 2, 2008. http://dx.doi.org/10.4468/2008.2.02salvioni

Schuiling Isabelle, Successful Market-Driven Organisations. The Procter and Gamble Case, Symphonya. Emerging Issues in Management (symphonya.unimib.it), n. 2, 2000-2001. http://dx.doi.org/10.4468/2001.2.06schuiling

Shingo Shigeo, A Study of the Toyota Production System from an Industrial Engineering Viewpoint (Produce What Is Needed, When It's Needed), Productivity Press Inc, New York, 1981.

Shingo Shigeo, Non-Stock Production, Productivity Press Inc., New York, 1988.

Tapscott Don, Williams Anthony D., Wikinomics. How Mass Collaboration Changes Everything, Penguin Group, New York 2006.

Webster Frederick E.Jr., Market-Driven Management, John Wiley \& Sons, New York, 2002.

Wind Jerry, Mahajan Vijay, Digital Marketing, Symphonya. Emerging Issues in Management (symphonya.unimib.it), n. 1, 2002.

http://dx.doi.org/10.4468/2002.1.04wind.mahajan

Zaloom Caitlin, Time, Space, and Technology in Financial Networks, in Castells Manuel (ed.), The Network Society. A Cross-Cultural Perspective, Edward Elgar, Northampton, 2004.

Zucchella Antonella, Network Social Responsibility, Symphonya. Emerging Issues in Management (symphonya.unimib.it), n. 2, 2007.

http://dx.doi.org/10.4468/2007.2.07zucchella 


\section{Notes}

${ }^{1}$ Cf. Silvio M. Brondoni, Market-Driven Management, Competitive Space and Global Network, Symphonya. Emerging Issues in Management (symphonya.unimib.it), n. 1, 2008.

${ }^{2}$ Cf. Silvio M. Brondoni, Managerial Economics and Global Competition, Symphonya. Emerging Issues in Management, (symphonya.unimib.it), n. 1, 2005.

${ }^{3}$ Cf. Silvio M. Brondoni, Market-Driven Management, Competitive Space and Global Network, Symphonya. Emerging Issues in Management, (symphonya.unimib.it), n. 1, 2008.

${ }^{4}$ Cf. Isabelle Schuiling, Successful Market-Driven Organisations. The Procter and Gamble Case, Symphonya. Emerging Issues in Management (symphonya.unimib.it), n. 2, 2000-2001.

${ }^{5}$ Cf. Silvio M. Brondoni, Ouverture de 'Marketing Research \& Global Markets', Symphonya. Emerging Issues in Management (symphonya.unimib.it), n. 2, 2003.

${ }^{6}$ Cf. Silvio M. Brondoni, Jean-Jacques Lambin, Ouverture de 'Brand Equity', Symphonya. Emerging Issues in Management, (symphonya.unimib.it), n. 1, 2000-2001.

7 Cf. Silvio M. Brondoni, Brand Equity and Brand Policy, Symphonya. Emerging Issues in Management (symphonya.unimib.it), n. 1, 2000-2001.

${ }^{8}$ Cf. Silvio M. Brondoni, Brand Policy and Brand Equity, Symphonya. Emerging Issues in Management (symphonya.unimib.it), n. 1, 2000-2001.

${ }^{9}$ Cf. Silvio M. Brondoni, Market-Driven Management, Competitive Custumer Value and Global Networks, Symphonya. Emerging Issues in Management (symphonya.unimib.it), n. 1, 2009.

${ }^{10}$ Cf. Jean-Jacques Lambin, Changing Market Relationships in the Internet Age, UCL, Louvain, 2008.

${ }^{11}$ Cf. Silvio M. Brondoni, Global Markets and Market-Space Competition, Symphonya. Emerging Issues in Management (symphonya.unimib.it), n. 1, 2002.

${ }^{12}$ Cf. Jean-Marc de Leerrsnyder, Corporate Culture and Geopolitics, Symphonya. Emerging Issues in Management (symphonya.unimib.it), n. 2, 2002.

${ }^{13}$ Cf. Jean-Jacques Lambin, Silvio M. Brondoni, Ouverture de 'Market-Driven Management', Symphonya. Emerging Issues in Management (symphonya.unimib.it), n. 2, 2000-2001.

${ }^{14}$ Cf. Fabio Albanese, Merchandising and Licensing to Improve Brand Equity. The Coca-Cola Case, Symphonya. Emerging Issues in Management (symphonya.unimib.it), n. 1, 2000-2001.

${ }^{15}$ Cf. Daniela M. Salvioni, Market-Driven Management and Corporate Governance, Symphonya. Emerging Issues in Management (symphonya.unimib.it), n. 2, 2008.

16 Cf. Jerry Wind, Vijay Mahajan, Digital Marketing, Symphonya. Emerging Issues in Management (symphonya.unimib.it), n. 1, 2002.

1734 see Margherita Corniani, Demand Bubble Management, Symphonya. Emerging Issues in Management (symphonya.unimib.it), n. 1, 2002.

18 Cf. Antonella Zucchella, Network Social Responsibility, Symphonya. Emerging Issues in Management (symphonya.unimib.it), n. 2, 2007.

${ }^{19}$ Cf. Silvio M. Brondoni, Global Markets and Market-Space Competition, Symphonya. Emerging Issues in Management (symphonya.unimib.it), n. 1, 2002.

${ }^{20}$ Cf. George S. Day, Market- Driven Winners, Symphonya. Emerging Issues in Management (symphonya.unimib.it), n. 2, 2000-2001.

${ }^{21}$ Cf. Margherita Corniani, Push and Pull Policy in Market-Driven Management, Symphonya. Emerging Issues in Management (symphonya.unimib.it), n. 1, 2008. 
22 Cf. Kofi Annan, The Gobal Compact. Corporate Leadership in the World Economy, Symphonya. Emerging Issues in Management (symphonya.unimib.it), n. 2, 2002.

${ }^{23}$ Cf. Elio Borgonovi, Sustainable Economic Growth in the Global Society, Symphonya. Emerging Issues in Management (symphonya.unimib.it), n. 2, 2007. 